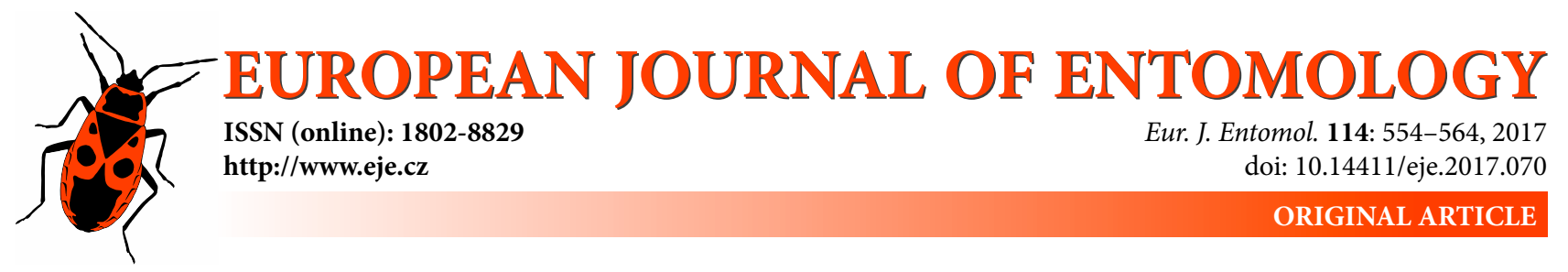

\title{
Windborne migration of Auchenorrhyncha (Hemiptera) over Britain
}

\author{
Don R. REYNOLDS ${ }^{1,2}$, JASON W. CHAPMAN ${ }^{3,4}$ and ALAN J.A. STEWART ${ }^{5}$ \\ ${ }^{1}$ Natural Resources Institute, University of Greenwich, Chatham, Kent ME4 4TB, UK; e-mail: D.Reynolds@greenwich.ac.uk \\ ${ }^{2}$ Rothamsted Research, Harpenden, Hertfordshire AL5 2JQ, UK \\ ${ }^{3}$ Centre for Ecology and Conservation, and Environment and Sustainability Institute, University of Exeter, Penryn, Cornwall \\ TR10 9EZ, UK; e-mail: j.chapman2@exeter.ac.uk \\ ${ }^{4}$ College of Plant Protection, Nanjing Agricultural University, Nanjing, China \\ ${ }^{5}$ School of Life Sciences, University of Sussex, Falmer, Brighton, BN1 9QG, UK; e-mail: a.j.a.stewart@sussex.ac.uk
}

Key words. Auchenorrhyncha, aerial sampling, flight, atmospheric transport, migration syndrome, life-history traits, host specificity, Britain

\begin{abstract}
Planthoppers (Delphacidae), leafhoppers (Cicadellidae) and froghoppers (Aphrophoridae) (Hemiptera: Auchenorrhyncha) caught during day and night sampling at a height of $200 \mathrm{~m}$ above ground at Cardington, Bedfordshire, UK, during eight summers (between 1999 and 2007) were consolidated with high-altitude catches made over England in the 1930s. Comparisons were made with other auchenorrhynchan trapping results from northwest Europe, which were indicative of migration. The migratory abilities in the species concerned were then interpreted in terms of various life-history traits or ecological characteristics, such as ontogenetic, diel and seasonal flight patterns, voltinism, habitat preferences, and host plant affinity. In contrast to some other areas of the world (North America, East Asia), the migratory abilities of most Auchenorrhyncha species in northwest Europe is poorly understood, and thus the present study draws together, and complements, fragmentary information on this topic as a basis for further research.
\end{abstract}

\section{INTRODUCTION}

Some members of the Auchenorrhyncha (Hemiptera) are noted long-distance migrants - they can ascend to high altitudes (Glick, 1939, 1960; Riley et al., 1991; Reynolds et al., 1999; Drake \& Reynolds, 2012), and are able to maintain continuous wing-beating for long periods of time while the wind transports them over great distances. In fact, the migration of the delphacid rice pests Sogatella furcifera (Horváth) (white-backed planthopper), Nilaparvata lugens (Stål) (brown planthopper) and Laodelphax striatella (Fallén) (small brown planthopper) from the East Asian mainland to Japan each year (Kisimoto \& Rosenberg, 1994; Otuka et al., 2010; Otuka, 2013), covering an overwater movement of $\sim 1000 \mathrm{~km}$, is one of the longest non-stop journeys in relation to body size of any animal migrant. Another remarkable instance was the mass invasion of the mid-Atlantic Ascension Island by the cicadellid Balclutha pauxilla Lindberg, probably from southwest Africa, more than $3000 \mathrm{~km}$ away (Ghauri, 1983). In North America, the annual long-distance migrations of the cicadellids Empoasca fabae (Harris) (potato leafhopper), Macrosteles quadrilineatus Forbes ( $=$ M. fascifrons; sixspotted or aster leafhopper) and Circulifer tenellus (Baker) (beet leafhopper) are well-known (Glick, 1960; Johnson,
1969; Taylor, 1985, 1989; Carlson et al., 1992; Taylor et al., 1995; Shields \& Testa, 1999).

Some of these plant- and leafhopper species make longrange poleward movements each summer from continuous breeding zones at lower latitudes, and they can be of immense economic importance due to their role as vectors of plant viruses, bacteria, and other pathogens or, in some cases, due to direct feeding damage to crops (e.g. Heong \& Hardy, 2009; Otuka, 2013; Chasen et al., 2014). In Africa, Cicadulina leafhoppers are major vectors of maize streak disease; Rose (1978) investigated the flight durations of various species and morphs and found that some of the long-flying forms could fly continuously for several hours, although the frequency distribution of durations was markedly skewed towards short-duration flights.

In Europe, damage to crops due to migrant Auchenorrhyncha is less significant than in the above-mentioned regions (but see Brčák, 1979; Lindsten, 1979) and, consequently, migration has been less intensively studied. Moreover, most of the detailed studies that have been made (Raatikainen, 1967; Raatikainen \& Vasarainen, 1973; Waloff, 1973; della Giustina \& Balasse, 1999), have involved trapping at relatively low heights above ground $(\leq 12.3 \mathrm{~m})$; sampling Auchenorrhyncha above the atmos- 
pheric surface layer is seldom undertaken. An exception was the study by Günthart (1988) who analysed the vertical distribution of leafhoppers, trapped up to $155 \mathrm{~m}$ above ground on a meteorological mast near Basle in Switzerland, but here the fauna was very different to that found in the studies in Britain, with only Conosanus obsoletus (Kirschbaum) (one specimen caught by Freeman, 1939) in common. We also note the capture of the leafhopper Arthaldeus pascuellus (Fallén) (referred to as Deltocephalus pascuellus) at 1000-1200 m over northern France in June 1934 during trapping from an aeroplane (Berland, 1935).

Even among macropterous flight-capable Auchenorrhyncha, the majority of flights undertaken are short duration 'flits' (sensu Southwood, 1960; Waloff, 1973) which are 'appetitive' in nature (i.e. low-altitude local flights concerned with feeding and reproduction) or, perhaps, some very short-range dispersal events. The present paper is concerned with windborne migratory movements, and we adopt the individual-based behavioural definition of migration formulated by J.S. Kennedy and developed by H. Dingle (see Dingle, 2014 pp. 14-15). For it to be likely that Auchenorrhyncha individuals are engaged in windborne migration, aerial samples must be taken well above an insect's 'flight boundary layer' (Taylor, 1974) - the layer of the atmosphere near the ground surface or plant canopy where the ambient wind speed is lower than the insect's self-powered flight speed. Drawing upon the work of L.R. Taylor and others, Teraguschi (1986) in his study of leafhoppers of an old-field site in Ohio, USA, espouses the view "that the crossing of the flight boundary layer interface is a highly programmed event" so that "aerial abundances are not simple functions of terrestrial abundances" - a standpoint with which we agree (see e.g. Reynolds et al., 2014). Günthart's (1988) samples were taken at several heights simultaneously and extended high above the ground, so she was able to estimate the thickness of the leafhopper flight boundary layer (viz. $\sim 20-30 \mathrm{~m}$ ). Southwood (1962) considered that Heteroptera caught above $\sim 15 \mathrm{~m}$ would be migrants rather than individuals engaged in short-duration 'flitting'. In the aerial sampling studies considered here, the Auchenorrhyncha trapped were flying at least several tens of metres above ground and were thus well above their flight boundary layer.

Some early researchers, sampling at relatively low heights above ground, may not have fully realized the movement potential of these Auchenorrhyncha, resulting in underestimates of migration distances. Insect ascent to the altitudes sampled by us at an updraft-assisted vertical speed of, say, $1 \mathrm{~m} / \mathrm{s}$, even if followed by immediate descent, would take a minimum of several minutes, which at ambient wind speeds recorded when hoppers were flying $(\sim 7 \mathrm{~m} / \mathrm{s})$ would result in a movement of at least several kilometres. Any tendency to maintain flapping flight at altitude would, of course, rapidly extend the migratory ambit.

In the present study, planthoppers (Delphacidae), leafhoppers (Cicadellidae) and froghoppers (Aphrophoridae) were sampled at a height of ca. $200 \mathrm{~m}$ above ground over southern England. We integrate these results with those from early (1930s) UK studies in which numbers of Auchenorrhyncha were captured aloft $(>50 \mathrm{~m})$ and which were identified to species level (Hardy \& Milne 1938; Freeman, $1939,1945)$. We also bring together other scattered records from the literature, which are indicative of migratory activity, for the British species of Auchenorrhyncha. Based on results from previous studies of migration in Auchenorrhyncha, especially in Europe, North America and East Asia, we test the following specific hypotheses:

- volant individuals will either belong to species that are always fully winged or be macropterous individuals of wing-polymorphic species;

- most flight activity will be nocturnal;

- aerial densities of Auchenorrhyncha will be greater under conditions of higher wind speeds, but will be unrelated to wind direction;

- the assemblage of volant Auchenorrhyncha will be characterised by species that are bivoltine, polyphagous and primarily associated with ephemeral or disturbed habitats, and that overwinter as eggs or nymphs rather than adults;

- sex ratios in aerial catches will not depart significantly from $1: 1$

\section{METHODS}

We took aerial samples of insects at ca. $200 \mathrm{~m}$ above ground with a drogue net of $1 \mathrm{~m}$ diameter aperture suspended from a tethered helium-filled kite-balloon (kytoon) (Fig. 1). The sampling site, at Cardington Airfield (52 $\left.06^{\prime} \mathrm{N}, 0^{\circ} 25^{\prime} \mathrm{W}\right)$, Shortstown, Bedfordshire, in southern England, has an official aircraft exclusion zone which allowed the kytoon to be flown above the Civil Aviation Authority limit of $60 \mathrm{~m}$. Sampling was carried out in the years 1999, 2000, and 2002-2007, in various months between May and early September, but mostly in July (Table 1). [The aerial netting was designed to support our radar observations (e.g. Hu et al., 2016), and insect numbers detected by the radar were extremely low outside the May-September period.]

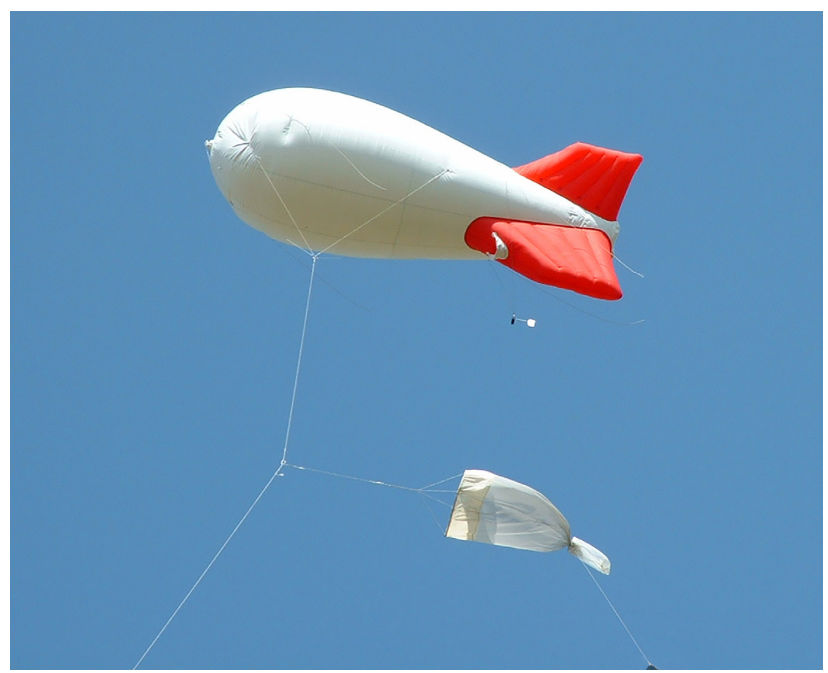

Fig. 1. Sampling insects at ca. $200 \mathrm{~m}$ above ground by means of a net attached to the tethering line of a 6-m long kytoon. The detachable bag at the end of the net has just been closed-off, prior to winching down of the kytoon to ground level and recovery of the sample. The wind-run meter can be seen suspended below the kytoon tail. 
Table 1. Auchenorrhyncha caught at high altitude (ca. 200 m a.g.I) at Cardington, Bedfordshire, UK, 1999-2007.

\begin{tabular}{|c|c|c|c|c|c|c|c|c|c|c|c|c|}
\hline & Year & 1999 & 2000 & 2002 & 2003 & 2004 & 2005 & 2006 & 2007 & \multirow{3}{*}{ Total } & \multirow{2}{*}{\multicolumn{2}{|c|}{ Sex }} \\
\hline & Sampling month(s) & July & July & July & $\begin{array}{l}\text { August } \\
\text {-Sept. }\end{array}$ & July & $\begin{array}{l}\text { June } \\
\text {-July }\end{array}$ & $\begin{array}{l}\text { August } \\
\text {-Sept. }\end{array}$ & $\begin{array}{c}\text { May- } \\
\text { July }\end{array}$ & & & \\
\hline & Total wind-run $(\mathrm{km})$ & 2847.2 & 2524.0 & 2273.0 & 2922.1 & 2610.0 & 3262.0 & 1370.0 & 2188.0 & & $\mathrm{~F}$ & $\mathrm{M}$ \\
\hline Family & Species & & & & & & & & & & & \\
\hline Delphacidae & $\begin{array}{l}\text { Javesella pellucida (Fab.) } \\
\text { Javesella dubia (Kirschbaum) } \\
\text { Muellerianella brevipennis (Boheman) }\end{array}$ & 17 & 3 & 15 & 1 & 2 & $\begin{array}{l}7 \\
1\end{array}$ & & $\begin{array}{r}77 \\
2\end{array}$ & $\begin{array}{r}122 \\
1 \\
2\end{array}$ & 63 & $\begin{array}{r}59 \\
1 \\
1\end{array}$ \\
\hline Cicadellidae & $\begin{array}{l}\text { Anaceratagallia ribauti (Ossiannilsson) } \\
\text { Anoscopus albifrons (L.) }\end{array}$ & & & 1 & & 1 & 2 & 1 & & $\begin{array}{l}1 \\
4\end{array}$ & $\begin{array}{l}1 \\
4\end{array}$ & \\
\hline & Deltocephalus pulicaris (Fallén) & 2 & & & 1 & & & 1 & & 4 & 1 & 3 \\
\hline & Arthaldeus pascuellus (Fallén) & & & & 9 & & 13 & 1 & & 23 & 19 & 4 \\
\hline & Psammotettix confinis (Dahlbom) & & 1 & & 1 & & 1 & & & 3 & 1 & 2 \\
\hline & Psammotettix nodosus (Ribaut) & 1 & & & & & & & & 1 & 1 & \\
\hline & Euscelis incisus (Kirshbaum) & & & & 1 & 1 & & & & 2 & 2 & \\
\hline & Streptanus sordidus (Zetterstedt) & & & & & & 1 & & & 1 & & 1 \\
\hline & Athysanus argentarius Metcalf & 1 & & & & & & & & 1 & & 1 \\
\hline & Macrosteles sp. & & & & & & 2 & & & 2 & 2 & \\
\hline & Empoasca decipiens (Paoli) & & & 1 & & 1 & & & & 2 & 2 & \\
\hline & Eurhadina pulchella (Fallén) & & & 1 & & & & & & 1 & 1 & \\
\hline & Eupteryx atropunctata (Goeze) & & & & & & 2 & & 1 & 3 & & 3 \\
\hline & Eupteryx urticae (F.) & & & & & & 3 & & & 3 & 2 & 1 \\
\hline & Eupterycyba jucunda (Herrich-Schaeffer) & & & & & 1 & & & & 1 & 1 & \\
\hline & Lindbergina aurovittata (Douglas) & & & & & 2 & & & & 2 & & 2 \\
\hline & Fagocyba cruenta (Herrich-Schaeffer) & & & 1 & & & & & & 1 & 1 & \\
\hline & Edwardsiana sp. & & & & & & 1 & & 1 & 2 & 2 & \\
\hline & Alnetoidea alneti (Dahlbom) & & & 1 & & 1 & & & & 2 & 2 & \\
\hline & Zyginidia scutellaris (Herrich-Schaeffer) & & & 2 & & & 4 & & 1 & 7 & 4 & 3 \\
\hline Aphrophoridae & Neophilaenus lineatus (L.) & & & 1 & & & & & & 1 & & 1 \\
\hline Total & & 21 & 4 & 23 & 13 & 9 & 37 & 3 & 82 & 192 & 110 & 82 \\
\hline Mean density $(r$ & numbers per $10^{5} \mathrm{~m}^{3}$ ) & 3.7 & 3.1 & 4.3 & 3.5 & 4.7 & 4.3 & 2.6 & 13.5 & & & \\
\hline
\end{tabular}

For aerial sampling purposes, the 24-h period was generally divided up as follows: $1 \mathrm{~h}$ around dusk $(\sim 21.00-22.00 \mathrm{~h}$ BST in July); night-time after the dusk period (various durations, occasionally until dawn); 'morning' (10.00-14:00 h), and afternoon (14:00-18:00). At the end of each sample period, the rear end of the net was closed off with a radio-controlled strangling device, and the kytoon was winched down to near ground level. A detachable bag containing the insect catch was unzipped from the end of the net and placed in a plastic killing bottle, and the wind run (in kilometres) was read off a meter (which was also suspended from the kytoon). The wind-run measurement for each sample period allowed the airflow through the net to be estimated so that catch numbers could be converted to aerial densities. Further details of kytoon-flying and aerial sampling procedures can be found elsewhere (Chapman et al., 2004; Reynolds et al., 2013). For our analyses, wind speeds were categorized as 'Low' $(0-<3 \mathrm{~m} / \mathrm{s})$, 'Medium' $(3-<5 \mathrm{~m} / \mathrm{s})$, 'Medium-high' $(5-<8 \mathrm{~m} / \mathrm{s})$, and 'High' $(\geq 8 \mathrm{~m} / \mathrm{s})$. Wind directions were categorised as North $\left(315-45^{\circ}\right)$, East $\left(45-135^{\circ}\right)$, South $\left(135-225^{\circ}\right)$, and West $\left(225-315^{\circ}\right)$.

A night-time sampling height of $200 \mathrm{~m}$ was chosen in order to take advantage of any layers of insects developing in the warm, fast-moving air (the boundary layer wind maximum) which tends to form near the top of the surface temperature inversion in clear weather (Drake \& Reynolds, 2012) - it was sensible to position the net within this airstream, rather than in the colder and stiller air nearer the ground. The choice of sampling height during the day is more arbitrary (because migrating insects may be circulated through various altitudes by convection), but the standard height of about $200 \mathrm{~m}$ was convenient and it was high enough to avoid captures of insects engaged in appetitive flights near the ground. The actual periods selected for sampling depended on the weather: apart from cold or wet conditions, when insect migration does not occur to any appreciable extent in Britain, kytoon- flying was not possible at times of significant lightning risk and during very strong winds. On a few days, winds at altitude proved to be too light (i.e. below $\sim 3 \mathrm{~m} / \mathrm{s}$ ) for efficient netting.

In the early UK studies, Hardy \& Milne (1938) used nets attached to kites, and samples containing Auchenorrhyncha were taken at various heights between 76 and $610 \mathrm{~m}$ at sites near Hull (Yorkshire), Dover (Kent) and Tetney (Lincolnshire). Freeman $(1939,1945)$ attached nets to tall radio masts at Tetney at three heights (i.e. 3, 54 and $84 \mathrm{~m}$ ), but only samples taken at his two upper heights were considered here because individuals caught at $3 \mathrm{~m}$ may have been engaged in appetitive flight rather than migration.

Catches from Cardington were sorted and preserved in a mixture of $95 \%$ ethanol and 5\% glycerol. Auchenorrhyncha present in the samples were later identified - by M.A. Salmon for 1999 samples, otherwise by A.J.A.S - using Le Quesne (1960, 1965, 1969) and Le Quesne \& Payne (1981). All specimens were identified to species with the exception of female Macrosteles and Edwardsiana which cannot be reliably determined beyond genus level. The nomenclature follows Wilson et al. (2015).

Auchenorrhyncha aerial densities obtained from the Cardington samples were compared for time of day categories, wind speed categories, and wind directions, using analyses of deviance based on generalised linear models with quasipoisson errors ( $R$ Core Team, 2016). Tukey multiple comparisons derived from these generalised linear models used the $\mathrm{R}$ multcomp package (Hothorn et al., 2008). Departure of sex-ratios from 1:1 in our samples was tested using chi square goodness-of-fit tests; it was not possible to include data from the earlier studies because they did not enumerate the sexes separately. Calculations of Shannon diversity and evenness indexes and Sørensen's index of similarity follow Magurran (2003). 


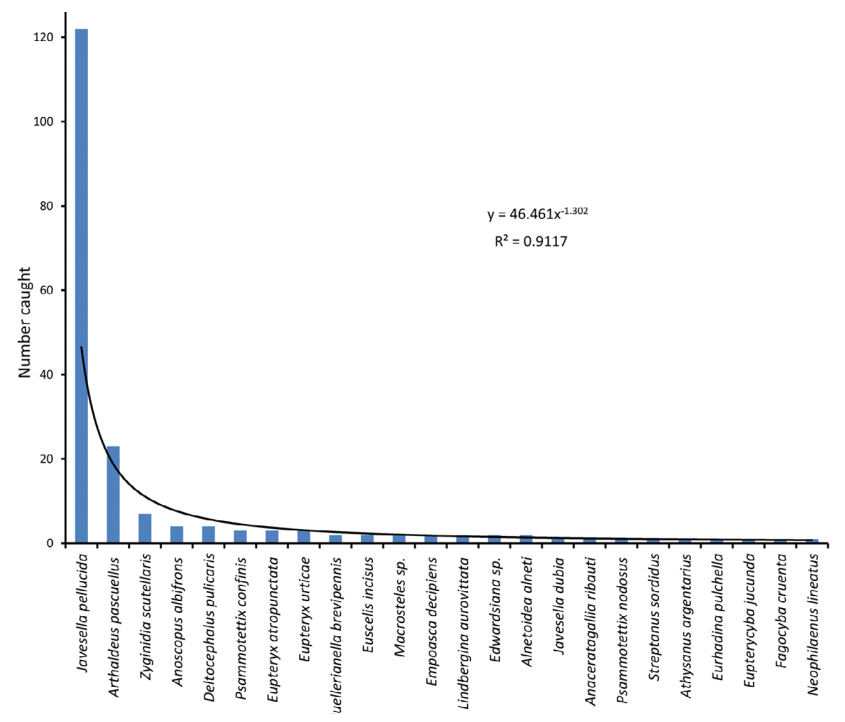

Fig. 2. The rank-abundance curve for Auchenorrhyncha species in aerial samples taken at Cardington, Bedfordshire, 1999-2007. A power-law trendline has been fitted to the data.

\section{RESULTS}

A total of 192 individual Auchenorrhyncha across 24 species were caught during the eight years of the present study at Cardington (Table 1). In comparison, 35 specimens of 16 species of Heteroptera were caught in the same samples (Reynolds et al., 2013). All Auchenorrhyncha specimens were macropterous including those of strongly wing-polymorphic species such as Javesella pellucida.

\section{Aerial densities}

The aerial density of Auchenorrhyncha in our samples between 1999 and 2007 ranged between 3.1 and 4.7 per $10^{5} \mathrm{~m}^{3}$ (Table 1). The average density for the 2007 season showed a higher value $\left(13.5\right.$ per $\left.10^{5} \mathrm{~m}^{3}\right)$ due to the presence of large numbers of $J$. pellucida. The highest density for this species was 30 per $10^{5} \mathrm{~m}^{3}$ in a sample taken on the morning of 24 July 2007.

\section{Diel flight periodicity}

Diel sampling period had a highly significant effect on the total aerial catch (Table 2 ) such that $86 \%$ of aerial samples that contained hoppers were taken in the morning or afternoon and $10 \%$ were taken at dusk (Fig. 3a); the latter may have signified an extension of daytime flight into the dusk period rather than a take-off at dusk. Sampling period also had a highly significant effect on the most common species, J. pellucida and Arthaldeus pascuellus, both of which were caught exclusively during the day. Only 4\% of the samples that contained hoppers were night samples (i.e. taken after $22.00 \mathrm{~h} \mathrm{BST}$ ); the species were singletons

Fig. 3. Aerial densities of all Auchenorrhyncha, and of the commonest two species (Javesella pellucida and Arthaldeus pascuellus) caught at $200 \mathrm{~m}$ a.g.I. at Cardington, Bedfordshire, in relation to (a) time of day/night, (b) wind speed, and (c) wind direction (see 'Methods' for categorization of sampling periods and wind speeds/ directions). Error bars indicate standard errors of the mean. Category means sharing lower case letters are not significantly different within species (Tukey's HSD post-hoc test, $p<0.05$ ). a

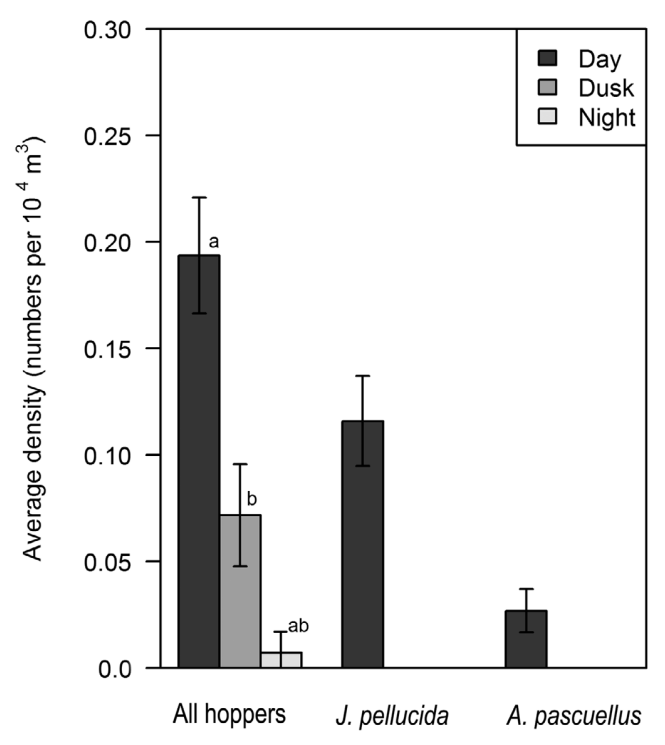

b

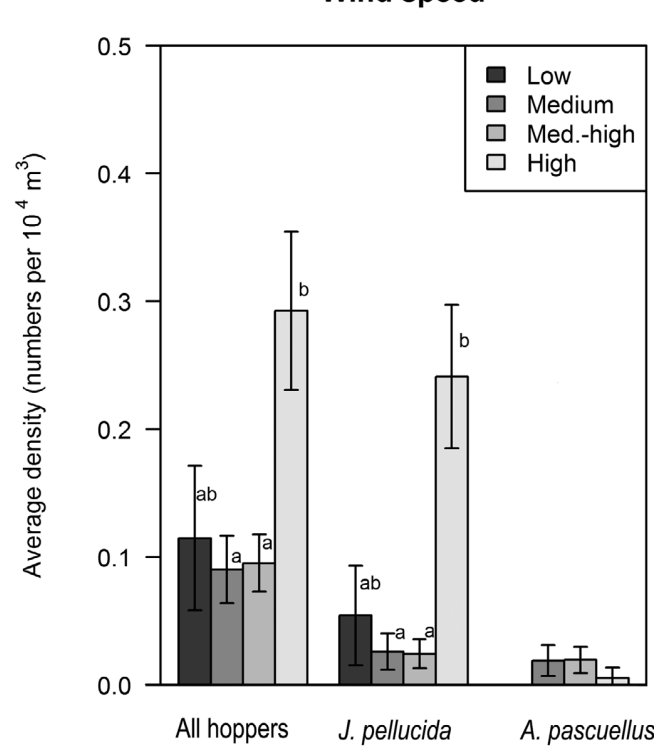

C

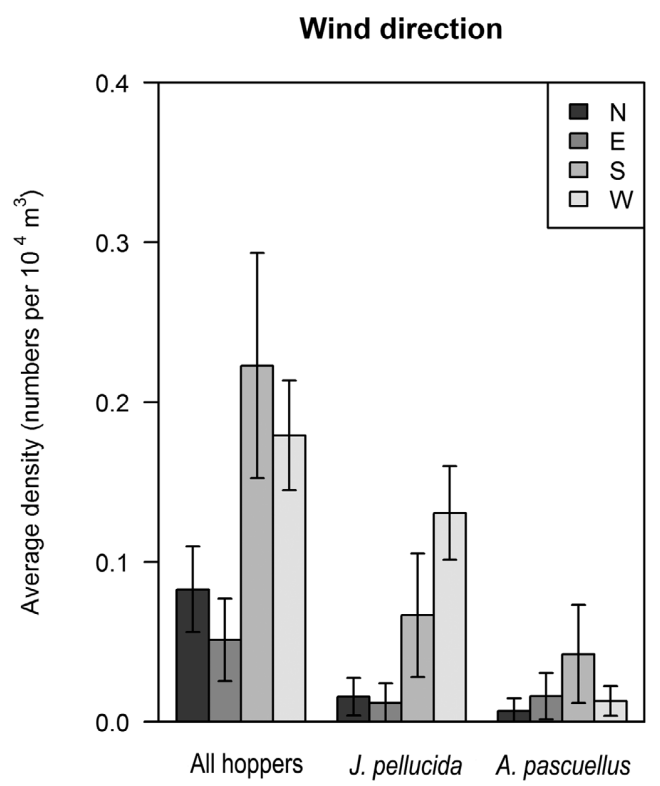


Table 2. Tests of the effect of time of day, wind speed and wind direction on aerial densities of Auchenorrhyncha at Cardington for: all species, Javesella pellucida and Arthaldeus pascuellus.

\begin{tabular}{|c|c|c|c|c|c|}
\hline Test & Factors (levels ${ }^{\dagger}$ ) & $\begin{array}{c}\text { Post-hoc } \\
\text { comparisons }\end{array}$ & All species & Javesella pellucida & $\begin{array}{l}\text { Arthaldeus } \\
\text { pascuellus }\end{array}$ \\
\hline $\begin{array}{l}\text { ANOVA (p-value associated } \\
\text { with F-statistic) }\end{array}$ & $\begin{array}{c}\text { Sampling period } \\
\text { (daytime, dusk, or night) }\end{array}$ & - & $\begin{array}{c}F(2,274)=9.64 \\
p<0.001\end{array}$ & $\begin{array}{c}F(2,274)=12.84 \\
p<0.001\end{array}$ & $\begin{array}{c}F(2,274)=13.22 \\
p<0.001\end{array}$ \\
\hline \multirow{3}{*}{$\begin{array}{l}\text { Multiple comparison of means: } \\
\text { Tukey HSD contrasts }\end{array}$} & \multirow{3}{*}{-} & Daytime / dusk & $\begin{array}{c}z=-2.35 \\
\text { corrected } p=0.042\end{array}$ & \multirow{3}{*}{ all NS } & \multirow{3}{*}{ all NS } \\
\hline & & Daytime / night & NS & & \\
\hline & & Dusk / night & NS & & \\
\hline $\begin{array}{l}\text { ANOVA (p-value associated } \\
\text { with F-statistic) }\end{array}$ & $\begin{array}{c}\text { Wind speeds } \\
\text { (low, medium, } \\
\text { medium-high, or high) }\end{array}$ & - & $\begin{array}{c}F(3,273)=4.17 \\
p=0.007\end{array}$ & $\begin{array}{c}F(3,273)=8.04 \\
p<0.001\end{array}$ & NS \\
\hline \multirow{3}{*}{$\begin{array}{l}\text { Multiple comparison of means: } \\
\text { Tukey HSD contrasts }\end{array}$} & \multirow{3}{*}{ - } & Medium / high & $\begin{array}{c}z=-2.95 \\
\text { corrected } p=0.015\end{array}$ & $\begin{array}{c}z=-3.27 \\
\text { corrected } p=0.006\end{array}$ & \multirow{3}{*}{ all NS } \\
\hline & & Medium-high / high & $\begin{array}{c}z=-3.22 \\
\text { corrected } p=0.006\end{array}$ & $\begin{array}{c}z=-3.85 \\
\text { corrected } p<0.001\end{array}$ & \\
\hline & & $\begin{array}{c}\text { All other wind } \\
\text { speed comparisons }\end{array}$ & NS & NS & \\
\hline $\begin{array}{l}\text { ANOVA ( } p \text {-value associated } \\
\text { with F-statistic) }\end{array}$ & $\begin{array}{l}\text { Wind direction } \\
(\mathrm{N}, \mathrm{E}, \mathrm{S}, \mathrm{W})\end{array}$ & - & $\begin{array}{c}F(3,273)=3.18 \\
p=0.024\end{array}$ & $\begin{array}{c}F(3,273)=4.97 \\
p=0.002\end{array}$ & NS \\
\hline $\begin{array}{l}\text { Multiple comparison of means: } \\
\text { Tukey HSD contrasts }\end{array}$ & - & $\begin{array}{l}\text { All wind direction } \\
\text { comparisons }\end{array}$ & NS & NS & \\
\hline
\end{tabular}

${ }^{\dagger}$ For definitions of levels, see Methods section.

of Psammotettix confinis, P. nodosus and Empoasca decipiens.

\section{Effects of wind speed and direction}

The aerial densities of Auchenorrhyncha over Cardington were significantly higher on occasions with high wind speeds, both for all species combined and for J. pellucida alone (but not for A. pascuellus) (Fig. 3b, Table 2); for example, there were significant Tukey HSD contrasts between hopper densities aloft in wind speeds of 5-8 m/s and speeds $\geq 8 \mathrm{~m} / \mathrm{s}$. Wind direction had a significant effect on numbers of all species combined and on J. pellucida in particular, but no significant contrasts emerged in the Tukey comparisons between particular wind directions (Fig. 3c, Table 2).

\section{Species composition of aerial samples}

Of the 24 species of Auchenorrhyncha caught at Cardington, the majority were leafhoppers (Cicadellidae, $\mathrm{n}=$ 20) compared to planthoppers (Delphacidae, $n=3$ ) and froghoppers (Aphrophoridae, $\mathrm{n}=1$ ). A rather typically shaped rank-abundance curve was obtained from these data (Fig. 2): only two species were at all frequent, with a long tail of species represented in low numbers or as singletons. The delphacid J. pellucida was by far the most frequently caught species (122 individuals) with the cicadellids A. pascuellus and Zyginidia scutellaris contributing the second and third highest numbers of specimens (23 and 7 , respectively). Shannon diversity (H') and evenness (E) were 0.69 and 0.50 respectively.

Table 3 compares our aerial catches with those made over England in the 1930s by Hardy \& Milne (1938) and Freeman $(1939,1945)$. The commonest ten species, in order of the grand total caught across the earlier studies and ours were: J. pellucida, A. pascuellus, Deltocephalus pulicaris, Psammotettix alienus, Eupteryx atropunctata,
Neophilaenus lineatus, Euscelis incisus, Z. scutellaris, P. confinis and Cicadula quadrinotata. Sørensen's qualitative index of community similarity between our samples and those of Freeman $(1939,1945)$ was low $(0.38)$; only eight out of 34 species across the two communities were recorded at both sites. The sample size recorded by Hardy $\&$ Milne $(1938)$ was too small $(n=19)$ to justify comparison with the other studies.

We also compared our data to the catches of Auchenorrhyncha in Rothamsted-type suction traps at $12.2 \mathrm{~m}$ above ground in France based on one complete year of sampling at about twelve sites (della Giustina \& Balasse, 1999). The standardized height of this suction trap was originally chosen in order to sample small insects (particularly aphids) that were likely to be long-distance migrants, i.e. the trap was designed so that the entrance was above the height of most local insect flight (Macauley et al., 1988). In spite of the two orders of magnitude difference between the sample size in England $(n=192)$ and that in France $(n=10,790)$, the latter were dominated by a similar list of species (totals in brackets): Z. scutellaris (4577), J. pellucida (3268) and Empoasca spp. (890) (including some Empoasca decipiens). Other species caught in England were also caught reasonably frequently in the French suction traps: Javesella dubia (184), Lindbergina aurovittata (97), Psammotettix alienus (30) and P. confinis (23).

\section{Phenology, voltinism, sex-ratio and overwintering stage}

Nearly all the species caught in aerial netting over England are known to undergo two or more annual generations routinely or facultatively (Table 4). Most specimens of $J$. pellucida were caught in mid to late July, particularly in late July 2007 . The sexes migrated in approximately equal proportions $\left(63 \bigcirc: 59 \hat{\jmath} ; \chi_{(1)}^{2}=0.13, \mathrm{p}=0.72\right)$. In contrast, we caught $A$. pascuellus from mid-June to early July, and 
Table 3. Comparison of catches of Auchenorrhyncha obtained during some aerial trapping studies over England.

\begin{tabular}{|c|c|c|c|c|c|c|c|c|}
\hline Study reference & & \multicolumn{2}{|c|}{$\begin{array}{l}\text { Freeman, } 1939 \\
1945\end{array}$} & \multicolumn{2}{|c|}{$\begin{array}{l}\text { Hardy \& Milne, } \\
1938\end{array}$} & \multicolumn{2}{|c|}{ Present study } & Totals \\
\hline Sampling location & & \multicolumn{2}{|c|}{$\begin{array}{l}\text { Tetney, near } \\
\text { Grimsby }\end{array}$} & \multicolumn{2}{|c|}{$\begin{array}{l}\text { Hull, Tetney, } \\
\text { Dover }\end{array}$} & \multicolumn{2}{|c|}{$\begin{array}{l}\text { Cardington, } \\
\text { Bedfordshire }\end{array}$} & \\
\hline Year(s) & & \multicolumn{2}{|c|}{1934,1935} & \multicolumn{2}{|c|}{$1932-1935$} & \multicolumn{2}{|c|}{$\begin{array}{l}1999,2000 \\
2002-2007\end{array}$} & \\
\hline Sampling period & & \multicolumn{2}{|c|}{ May-September } & \multicolumn{2}{|c|}{ June-October } & \multicolumn{2}{|c|}{$\begin{array}{l}\text { May-early } \\
\text { September }\end{array}$} & \\
\hline Time of sampling & & \multicolumn{2}{|c|}{ Day only } & \multicolumn{2}{|c|}{ Day only } & \multicolumn{2}{|c|}{ Day and night } & \\
\hline Height of sampling & & \multicolumn{2}{|c|}{54 and 84 m only * } & \multicolumn{2}{|c|}{$61-610 \mathrm{~m}$} & \multicolumn{2}{|c|}{ ca. $200 \mathrm{~m}$} & \\
\hline $\begin{array}{l}\text { Auchenorrhynchan superfamily, } \\
\text { family \& species }\end{array}$ & $\begin{array}{l}\text { Species name in Freeman, } \\
\text { or Hardy \& Milne (if different) }\end{array}$ & Number & $\%$ & Number & $\%$ & Number & $\%$ & \\
\hline $\begin{array}{l}\text { Fulgoroidea } \\
\quad \text { Delphacidae } \\
\text { Kelisia vittipennis (Sahlberg) } \\
\text { Muellerianella brevipennis (Boheman ) } \\
\text { Javesella pellucida (F.) } \\
\text { Javesella dubia (Kirschbaum) } \\
\text { Genus uncertain }{ }^{\dagger}\end{array}$ & $\begin{array}{l}\text { Liburnia pellucida } \\
\text { Liburnia sp. }\end{array}$ & $\begin{array}{l}3 \\
1 \\
\end{array}$ & $\begin{array}{l}1.97 \\
0.66 \\
\end{array}$ & 3 & $\begin{array}{r}5.26 \\
15.79\end{array}$ & $\begin{array}{r}2 \\
122 \\
1\end{array}$ & $\begin{array}{r}1.04 \\
63.54 \\
0.52\end{array}$ & $\begin{array}{r}1 \\
2 \\
128 \\
1\end{array}$ \\
\hline \multicolumn{9}{|l|}{ Membracoidea } \\
\hline $\begin{array}{l}\text { Anaceratagallia ribauti (Ossiannilsson) } \\
\text { Anoscopus albifrons (L.) }\end{array}$ & & & & & & $\begin{array}{l}1 \\
4\end{array}$ & $\begin{array}{l}0.52 \\
2.08\end{array}$ & $\begin{array}{l}1 \\
4\end{array}$ \\
\hline Deltocephalus pulicaris (Fallén) & & 20 & 13.16 & 2 & 10.53 & 4 & 2.08 & 26 \\
\hline $\begin{array}{l}\text { Turrutus socialis (Flor) } \\
\text { Errastunus ocellaris (Fallén) }\end{array}$ & $\begin{array}{l}\text { Deltocephalus socialis } \\
\text { Deltocephalus ocellaris }\end{array}$ & 5 & 3.29 & 1 & 5.26 & & & $\begin{array}{l}1 \\
5\end{array}$ \\
\hline Arthaldeus pascuellus (Fallén) & Deltocephalus pascuellus & 11 & 7.24 & 1 & 5.26 & 23 & 11.98 & 35 \\
\hline $\begin{array}{l}\text { Psammotettix confinis (Dahlbom) } \\
\text { Psammotettix nodosus (Ribaut) }\end{array}$ & Deltocephalus thenii & 5 & 3.29 & & & $\begin{array}{l}3 \\
1\end{array}$ & $\begin{array}{l}1.56 \\
0.52\end{array}$ & $\begin{array}{l}8 \\
1\end{array}$ \\
\hline Psammotettix alienus (Dahlbom) & Deltocephalus striatus & 19 & 12.50 & 1 & 5.26 & & & 20 \\
\hline Conosanus obsoletus (Kirshbaum) & Athysanus obsoletus & 1 & 0.66 & & & & & 1 \\
\hline Euscelis incisus (Kirshbaum) & Athysanus plebejus & 7 & 4.61 & 1 & 5.26 & 2 & 1.04 & 10 \\
\hline Euscelis lineolatus Brullé & Athysanus lineolatus & 6 & 3.95 & & & & & 6 \\
\hline Streptanus aemulans (Kirshbaum) & Athysanus sahlbergi & 1 & 0.66 & & & & & 1 \\
\hline Streptanus sordidus (Zetterstedt) & & & & & & 1 & 0.52 & 1 \\
\hline Athysanus argentarius Metcalf & & & & & & 1 & 0.52 & 1 \\
\hline Rhopalopyx adumbrata (Sahlberg) & Stictocoris preyssleri & & & 1 & 5.26 & & & 1 \\
\hline Mocydia crocea (Herrich-Schaeffer) & & & & 1 & 5.26 & & & 1 \\
\hline Cicadula quadrinotata (Fab.) & Limotettix quadrinotata & 1 & 0.66 & 1 & 5.26 & & & 2 \\
\hline Elymana sulphurella (Zetterstedt) & Limotettix sulphurella & 1 & 0.66 & & & & & 1 \\
\hline Macrosteles sexnotatus (Fallén) & Cicadula sexnotata & 25 & 16.45 & 6 & 31.58 & & & 31 \\
\hline Macrosteles sp. & & & & & & 2 & 1.04 & 2 \\
\hline Empoasca decipiens (Paoli) & & & & & & 2 & 1.04 & 2 \\
\hline Eurhadina pulchella (Fallén) & & & & & & 1 & 0.52 & 1 \\
\hline Eupteryx atropunctata (Goeze) & Eupteryx atropunctatus & 17 & 11.18 & & & 3 & 1.56 & 20 \\
\hline Eupteryx urticae (Fab.) & & & & & & 3 & 1.56 & 3 \\
\hline Eupterycyba jucunda (Herrich-Schaeffer) & & & & & & 1 & 0.52 & 1 \\
\hline Lindbergina aurovittata (Douglas) & & & & & & 2 & 1.04 & 2 \\
\hline Fagocyba cruenta (Herrich-Schaeffer) & & & & & & 1 & 0.52 & 1 \\
\hline Edwardsiana sp. & & & & & & 2 & 1.04 & 2 \\
\hline Alnetoidea alneti (Dahlbom) & & & & & & 2 & 1.04 & 2 \\
\hline Zyginidia scutellaris (Herrich-Schaeffer) & Erythroneura scutellellaris & 3 & 1.97 & & & 7 & 3.65 & 10 \\
\hline Genus uncertain ${ }^{\dagger}$ & Deltocephalus spp. & 4 & 2.63 & & & & & 4 \\
\hline Genus uncertain ${ }^{\dagger}$ & Cicadula sp. & 1 & 0.66 & & & & & 1 \\
\hline Unidentified cicadellids & & 6 & 3.95 & & & & & 6 \\
\hline \multicolumn{9}{|l|}{ Cercopoidea } \\
\hline Philaenus spumarius (L.) & & 1 & 0.66 & & & & & 1 \\
\hline Neophilaenus lineatus (L.) & Philaenus lineatus & 14 & 9.21 & & & 1 & 0.52 & 15 \\
\hline Total Auchenorrhyncha & & 152 & 100 & 19 & 100 & 192 & 100 & 362 \\
\hline Total insects and \% Auchenorrhyncha & & 7748 & 1.96 & 839 & 2.26 & 17752 & 1.08 & \\
\hline
\end{tabular}

* Freeman's samples taken at his lowest height (3 $\mathrm{m}$ above ground) were omitted. ${ }^{\dagger}$ The genus given in Freeman (1939) has now been split into several genera.

from late August to early September, but as significantly more females than males $\left(19: 4, \chi_{(1)}^{2}=9.78, \mathrm{P}=0.002\right)$. The ratio of females to males amongst the remaining species combined was $1.5: 1$ but this difference was not formally significant $\left(\chi_{(1)}^{2}=1.72, \mathrm{p}=0.19\right)$.

The proportion of all species caught in aerial netting over England (Table 4) adopting the different stages (egg, nymph, adult) for overwintering did not differ significantly from the proportions $(64 \%, 19 \% \& 16 \%$ respectively) given by Nickel (2003) for the complete Auchenorrhyncha fauna in Germany $\left(\chi_{(2)}^{2}=1.75, \mathrm{p}=0.42\right.$; for this comparison, Euscelis incisus was treated as split equally between overwintering in the egg and nymphal stages). 
Table 4. Information on habitat, host plant specificity, overwintering stage and number of generations for Auchenorrhyncha species caught by aerial netting over England. Species caught as singletons are not included.

\begin{tabular}{|c|c|c|c|c|c|c|}
\hline $\begin{array}{l}\text { Species (in order of } \\
\text { abundance in aerial } \\
\text { samples) }\end{array}$ & $\begin{array}{l}\text { Total } \\
\text { number } \\
\text { caught }\end{array}$ & Habitat type (in UK) * & $\begin{array}{l}\text { Host plant } \\
\text { specificity } \ddagger\end{array}$ & $\begin{array}{l}\text { Over- } \\
\text { wintering } \\
\text { stage }\end{array}$ & $\begin{array}{c}\text { No. of } \\
\text { annual } \\
\text { generations }\end{array}$ & $\begin{array}{l}\text { Reference for overwintering stage } \\
\text { and voltinism (in England, if available, } \\
\text { otherwise Germany) }\end{array}$ \\
\hline Javesella pellucida & 128 & $\begin{array}{l}\text { Grassland, sedges, } \\
\text { cereal crops }\end{array}$ & $\mathrm{p}$ & $\mathrm{N}$ & 2 & Waloff \& Solomon, 1973; Morris, 1990a, b \\
\hline Arthaldeus pascuellus & 35 & Grassland & 01 & $\mathrm{e}$ & 2 & Waloff \& Solomon, 1973 \\
\hline Macrosteles sexnotatus & 31 & $\begin{array}{l}\text { Grassland, clover } \\
\text { (Trifolium spp.) }\end{array}$ & $\mathrm{p}$ & e & 2 & Waloff \& Solomon, 1973 \\
\hline Deltocephalus pulicaris & 26 & $\begin{array}{l}\text { Grassland, particularly } \\
\text { in short grasses }\end{array}$ & 01 & e & 2 & Waloff, 1973 \\
\hline Psammotettix alienus & 20 & Grassland & 01 & e & $2^{\dagger}$ & $\begin{array}{l}\text { Nickel \& Remane, } 2002 ;{ }^{\dagger} 3 \text { generations } \\
\text { in a warm year in Saxony-Anhalt, } \\
\text { Germany (Manurung et al., 2005) }\end{array}$ \\
\hline Eupteryx atropunctata & 20 & $\begin{array}{l}\text { Primarily on mallow } \\
\text { (Malva spp.), sage (Salvia } \\
\text { officinalis) and potato } \\
\text { (Solanum tuberosum) }\end{array}$ & 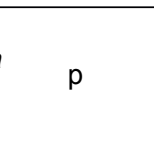 & e & 2 & Le Quesne \& Payne, 1981 \\
\hline Euscelis incisus & 10 & Grassland & 02 & $\mathrm{e}, \mathrm{N}$ & $2^{\S}$ & $\begin{array}{c}8^{r^{\text {rd }}} \& 4^{\text {th }} \text { instar nymphs of 3rd generation } \\
\text { may overwinter in mild winters } \\
\text { (Müller, 1981) }\end{array}$ \\
\hline Zyginidia scutellaris & 10 & Grassland & 01 & A & 3 & Waloff, 1994 \\
\hline Psammotettix confinis & 8 & Grassland & 01 & e & 2 & Waloff \& Solomon, 1973 \\
\hline Errastunus ocellaris & 5 & Grassland & 01 & e & 2 & $\begin{array}{c}\text { Waloff \& Solomon, 1973; Waloff \& } \\
\text { Thompson, } 1980\end{array}$ \\
\hline Anoscopus albifrons & 4 & Grassland & 01 & $\mathrm{e}$ & 1 & Nickel \& Remane, 2002 \\
\hline Eupteryx urticae & 3 & $\begin{array}{l}\text { Nettle (Urtica dioica) } \\
\text { and spreading pellitory } \\
\text { (Parietaria judaica) }\end{array}$ & $\mathrm{m} 1$ & e & 2 & Stewart, 1988 \\
\hline $\begin{array}{l}\text { Muellerianella } \\
\text { brevipennis }\end{array}$ & 2 & $\begin{array}{c}\text { Tussock grass } \\
\text { (Deschampsia cespitosa) } \\
\end{array}$ & $\mathrm{m} 1$ & e & $1-2$ & Nickel \& Remane, 2002 \\
\hline Cicadula quadrinotata & 2 & $\begin{array}{l}\text { Damp grasslands, rushes } \\
\text { and sedges }\end{array}$ & $\mathrm{m} 2 ?$ & e & $1-2$ & Nickel \& Remane, 2002 \\
\hline Empoasca decipiens & 2 & $\begin{array}{l}\text { Low vegetation, vege- } \\
\text { table crops, and fruit trees }\end{array}$ & $\mathrm{p}$ & A & $2+$ part 3 & Alford, 2014 \\
\hline Lindbergina aurovittata & 2 & $\begin{array}{l}\text { Various deciduous trees } \\
\text { (esp. oak - Quercus } \\
\text { robur) and brambles } \\
\text { (Rubus spp.) }\end{array}$ & $\mathrm{p}$ & e & 2 & $\begin{array}{l}\text { Nickel \& Remane, 2002. In Wales, } \\
\text { the first generation is found on brambles, } \\
\text { the second on other deciduous trees } \\
\text { (Claridge \& Wilson, 1978) }\end{array}$ \\
\hline Alnetoidea alneti & 2 & Deciduous trees & $\mathrm{p}$ & e & $1-2$ & $\begin{array}{c}1 \text { generation in South Wales (Claridge } \\
\text { \& Wilson, 1976); } 2 \text { generations in Germany } \\
\text { (Nickel \& Remane, 2002) }\end{array}$ \\
\hline
\end{tabular}

\section{Species' habitat associations}

The species caught are nearly all eurytopic or pioneer species with a wide geographic range, feeding on ruderal plants (such as nettle (Urtica dioica) in the case of Eupteryx urticae) or vegetable crops (e.g. Empoasca decipiens) and exploiting highly disturbed habitats such as intensivelymanaged grasslands or cereal cultivations ( $J$. pellucida, D. pulicaris, Z. scutellaris) (Table 4). Only two species are arboricolous, Lindbergina aurovittata and Alnetoidea alneti, both of which are polyphagous, an unusual strategy for tree-dwellers. Generally, the species caught were polyphagous or 1st degree oligophagous (according to the categorisation of Nickel \& Remane, 2002) (see Table 4).

\section{DISCUSSION}

Most of our predictions, based on the results of previous studies in various regions of the world on migration in Auchenorrhyncha, were supported. Unsurprisingly, all individuals in the aerial samples were macropterous. This characteristic, together with the sampling height, indicates that all individuals caught were actively migrating rather than being accidently caught up in convective up-draughts. In fact, small insects aloft in daytime convective conditions display distinctive behaviours with respect to the air column in which they are flying (Wainwright et al., 2017).

\section{Aerial densities}

Aerial densities of Auchenorrhyncha estimated from our samples were rather low, although not unusually so, for 
small insects flying at these altitudes in Britain (c.f. Johnson, 1969). For comparison, we note that aerial densities of the brown planthopper ( $N$. lugens) in south-east Asia can be two orders of magnitude higher during peak migration periods (see Table 10.2 in Drake \& Reynolds, 2012).

\section{Diel flight periodicity}

Information on diel flight periodicity from our sampling indicates that migration in British Auchenorrhyncha, contrary to our initial hypothesis, is largely a daytime or crepuscular activity. This is in distinct contrast to the long nocturnal migrations found in some North American and East Asian species (e.g. Taylor \& Reling, 1986; Riley et al., 1991; Carlson et al., 1992; Kisimoto \& Rosenberg, 1994; Reynolds et al., 1999). This may well be because nocturnal air temperatures in Britain and northern Europe are often below thresholds for flight (Raatikainen, 1967; Raatikainen \& Vasarainen, 1973), but daytime flight does have the advantage that, during sunny weather, migrants can utilise convective lift to gain height, thus reducing power consumption needed for migratory flight. As mentioned above, many small migratory insect taxa are similarly adapted (Wainwright et al., 2017).

\section{Effects of wind speed and direction}

The reason for increased aerial densities associated with high wind speeds is not clear, although we note that in some aphids, much migration takes place in fairly windy weather (lulls in the wind permit take-off) (Johnson, 1954; Walters \& Dixon, 1984). The lack of an association with any particular wind direction accords with small insects like aphids that do not seem to fly preferentially on winds from a particular direction (Taylor et al., 1979; Hu et al., 2016), although the leafhopper E. fabae in northeastern USA constitutes a known exception. In late summer, $E$. fabae ascending at dusk show an adaptive preference for flight on winds from the north which occur immediately after the passage of a cold front (Taylor \& Reling, 1986; Shields \& Testa, 1999) - in this case, the increased flight activity seems to be stimulated by falling air pressure.

\section{Voltinism, phenology, overwintering stage and sex-ratio in common migrant species}

Auchenorrhyncha assemblages in relatively stable undisturbed habitats such as low-input grasslands tend to be dominated by univoltine species (Novotny, 1994a, 1995; Nickel, 2003; Nickel \& Achtziger, 2005). Conversely, species found in disturbed habitats tend to be bivoltine or polyvoltine. The great majority of species in our study belonged to the latter ecological grouping. Some bivoltine leafhopper species show different levels of flight activity between generations (Nickel, 2003) but even so, having more than one generation per year would enhance the ability of the species to track temporally variable stands of host-plants.

$J$. pellucida is bivoltine in England with flight in both generations, but with macroptery particularly dominant in adults of the second generation (Waloff, 1973). The specimens caught in in our study in July evidently rep- resent second generation migrants (c.f. Fig. 4 in Waloff, 1973). The two peaks of $A$. pascuellus, in early and late summer, probably represent the migration of the first and second generations of this bivoltine species (see seasonal occurrence of adults in Waloff \& Solomon, 1973). Among the species of grassland leafhoppers she studied, Waloff (1973) inferred that A. pascuellus had rather low powers of dispersal, based on the relationship between numbers in traps at 1.2 and $9 \mathrm{~m}$ above ground. While not directly refuted by our data - we had no information on ground populations - this contention seems unlikely in view of our high-altitude catches. Specimens of the multivoltine Z. scutellaris, captured between mid-June and mid-July, were likely to have been first generation adults (Waloff, 1994). The large numbers of $Z$. scutellaris caught in French suction traps at the end of July / beginning of August was attributed to a generation produced on maize cultivations (della Giustina \& Balasse, 1999). The two Macrosteles females (of unknown species) caught in our samples in June were presumably first generation individuals. Macrosteles sexnotatus was the most abundant species in Freeman's (1939) study, in which captures in June and September represent the first and second generation adults, respectively, according to Waloff \& Solomon's (1973) phenology for $M$. laevis/sexnotatus in southern England.

The leafhoppers caught by our aerial trapping were mostly species which overwinter in the egg stage, although the planthopper $J$. pellucida overwinters as a nymph. This seems to be the typical situation in the cicadomorph and fulgoromorph Auchenorrhyncha respectively (see Table 37 in Nickel, 2003), however, so it is not clear whether this difference represents an ecological adaption or just a phylogenetic constraint. Zyginidia scutellaris and E. decipiens are exceptions to the usual leafhopper pattern in that they overwinter as adults, but these species are unusual in any case as they tend to multivoltinism in England. It should be noted that our sampling period did not include very early (March) or late (November) in the season, with the consequence that we may have missed other species that often overwinter as adults (e.g. Balclutha spp., Zygina spp. and some Idiocerinae). However, Freeman (1939) who did sample from March to November in one year (1935) from his masts in Lincolnshire, caught very few Auchenorrhyncha outside the May-September period ( $N$. lineatus was trapped in November).

Our prediction that migrating individuals would have an equal sex ratio was supported by $J$. pellucida but not $A$. pascuellus. The female-biased sex ratio in A pascuellus in our samples differs from the near-equal sex ratio $(1.1$ : $\left.1 \delta^{\pi}\right)$ in Waloff's (1973) suction trap samples taken nearer the ground (at or below $12.2 \mathrm{~m}$ ).

\section{Species composition of aerial samples}

The qualitative similarity between our catches of Auchenorrhyncha and those in suction traps at $12.2 \mathrm{~m}$ above ground in France based on much wider geographical and seasonal coverage (della Giustina \& Balasse, 1999), gives us confidence that we are sampling similar ecological phenomena. 
The dominance of $J$. pellucida in our catches is, perhaps, not surprising as the species is very common; Nickel (2003) states that it is probably the most common auchenorrhynchan in most parts of cultivated lowlands in Central Europe. It is also a noted migrant, often contributing a high proportion of the catch in traps at heights of $\sim 10-12 \mathrm{~m}$ above ground in southern England (Waloff, 1973), France (della Giustina \& Balasse, 1999) and Finland (Raatikainen \& Vasarainen, 1973), although not locally the most abundant planthopper. It is wing-polymorphic, but it is one of rather few delphacids in which macropters dominate, presumably reflecting its dispersal tendencies. It is a vector of several plant disease agents including Oat sterile dwarf virus and European wheat striate mosaic virus (Brčák, 1979; Lindsten, 1979).

The occurrence of certain individual species in our catches deserves comment. The large and distinctive leafhopper, Athysanus argentarius, appeared once in our aerial samples and has been discussed previously (Salmon \& Chapman, 2000) in respect of its northward range expansion in recent years in Britain. Teraguchi (1986) referred to A. argentarius as a classic example of the oogenesis/flight syndrome of Johnson (1969), as most of the catch in his aerial traps were females, but only a very small percentage of these were sexually mature.

The presence of the leafhopper Anoscopus albifrons, albeit in small numbers (4), is remarkable given that this species is normally considered to dwell close to the ground, being most frequently sampled by pitfall traps or powerful suction sampling (Stewart, 2002). The same comment would apply to Anaceratagallia ribauti, although only a singleton of this species was caught.

Finally, we note that catches of small insects over the sea far from land are also indicative of windborne migration; in this context two 'Empoasca flavescens' [now Empoasca vitis (Göthe)] and one $J$. pellucida were reported in samples taken in 1938 over the North Sea (with nets attached to ships' mast-heads) (Hardy \& Cheng, 1986).

\section{CONCLUSIONS}

The species caught by aerial trapping were certainly not a random assortment of the approximately 150 Auchenorrhyncha regarded as common in Britain (see http://www. ledra.co.uk/species.html) but, in the main, they seem to be a guild of species exploiting the same class of resources in a similar manner, with migration constituting an important element of their life-cycle. In the first instance, migration abilities will of course depend on macroptery, and will also be related to age and sexual maturity. Where the matter has been considered, migratory flight in European Auchenorrhyncha seems to occur fairly soon (a few days) after the appearance of the first adults, e.g. in $J$. pellucida and $D$. pulicaris (Raatikainen, 1967, Raatikainen \& Vasarainen, 1973), and this timing would also have to take into account any periods where weather was unfavourable for flight. So we can conclude that migration occurs in sexually immature adults, and that mature ones tend to 'flit' or even show loss of flight capacity (Waloff, 1973). Thus, several of the
Auchenorrhyncha considered here show evidence of the oogenesis-flight syndrome (as found in planthoppers and leafhoppers from other regions, e.g. Teraguschi, 1986; Kisimoto \& Rosenberg, 1994; Shields \& Testa, 1999).

After these physiological and morphological aspects of the migration syndrome (Dingle, 2014; Chapman et al., 2015) are taken into account, the species found in our samples exemplify a colonising 'life-style' with the associated relationships between migration propensity and the durational stability and isolation of the habitat. In fact, several careful assessments have confirmed the relationship between the migratory capability of Auchenorrhyncha and the ephemerality of their habitats (e.g. Denno et al., 1991, 1996, 2001; Novotný, 1994b), with the proviso that species associated with three-dimensional habitats (trees, tall herbs) tend to exhibit monomorphic macroptery because of the need for wings to negotiate around the complex host-plant architecture (Waloff, 1983; Denno et al., 2001). The species regularly encountered in aerial samples (Table 4) tend to be common 'r-selected' opportunists, characteristically found in disturbed grasslands or in other early-successional and ephemeral habitats (Morris, 1990a; Nickel, 2003; Nickel \& Hildebrandt, 2003). They are also characterized by low food specificity - polyphagous species are known to be associated with transient habitats, unlike monophagous specialists, which prefer more stable ones (Novotny, 1994a; Nickel, 2003). Arboricolous species were much less frequently captured in this, and previous, studies of aerial migration, and those that were caught tended to be polyphagous on a range of deciduous trees.

In summary, we consider that the captures of Auchenorrhyncha documented here do not represent haphazard events, but are indicative of regular migrations in the upper air as an adaptation to a colonising way of life. Clearly more data are required to support this view, particularly in the case of the species where only singletons were collected, but we hope that this preliminary contribution will stimulate further work on the migration syndromes of this group of insects.

ACKNOWLEDGEMENTS. We are grateful to the Director of the Meteorological Research Unit (of the Met Office, UK) for permission to operate our kytoon within the aircraft exclusion zone at Cardington, and thank D. Bamber and other Met Office staff for advice on the practical and administrative aspects of the balloon flying operations. S. Dunn, R. Selby, D. Sivell, E. Smith and C. Wood assisted with the balloon handling and sorting of the aerial catches during particular field trips. Special thanks are due to A. Smith (Rothamsted) for invaluable help in organising the aerial sampling programmes. S. Young (NRI) provided help with statistics. Rothamsted Research is a national institute of bioscience strategically funded by the UK Biotechnology and Biological Sciences Research Council (BBSRC). The project was supported by the BBSRC grant (BB/J004286/1) to J.W.C.

\section{REFERENCES}

Alford D.V. 2014: Pests of Fruit Crops: A Color Handbook. 2nd ed. CRC Press, Boca Raton, FL, 462 pp.

BerLAND L. 1935: Premier résultats de mes recherches en avion sur la faune et la flore atmosphériques. - Ann. Soc. Entomol. Fr. 104: 73-96. 
BRČÁK J. 1979: Leafhopper and planthopper vectors of plant disease agents in central and southern Europe. In Maramorosch K. \& Harris K.F. (eds): Leafhoppers Vectors and Plant Disease Agents. Academic Press, New York, pp. 97-154.

Carlson J.D., Whalon M.E., Landis D.A. \& Gage S.H. 1992: Springtime weather patterns coincident with long-distance migration of potato leafhopper into Michigan. - Agric. For. Meteorol. 59: 183-206.

Chapman J.W., Reynolds D.R., Smith A.D., Smith E.T. \& WoIwOD I.P. 2004: An aerial netting study of insects migrating at high-altitude over England. - Bull. Entomol. Res. 94: 123136.

Chapman J.W., Reynolds D.R. \& Wilson K. 2015: Long-range seasonal migration in insects: mechanisms, evolutionary drivers and ecological consequences. - Ecol. Lett. 18: 287-302.

Chasen E.M., Dietrich C., Backus E.A. \& Cullen E.M. 2014: Potato leafhopper (Hemiptera: Cicadellidae) ecology and integrated pest management focused on alfalfa. $-J$. Integr. Pest Manag. 5: A1-A8.

Claridge M.F. \& Wilson M.R. 1976: Diversity and distribution patterns of some mesophyll-feeding leafhoppers of temperate woodland canopy. - Ecol. Entomol. 1: 231-250.

Claridge M.F. \& Wilson M.R. 1978: Seasonal changes and alternation of food plant preference in some mesophyll-feeding leafhoppers. - Oecologia 37: 247-255.

Della Giustina W. \& Balasse H. 1999: Gone with the wind: Homoptera Auchenorrhyncha collected by the French network of suction traps in 1994. - Marburg. Entomol. Publ. 3: 7-42.

Denno R.F., Roderick G.K., Olmstead K.L. \& Dobel H.G. 1991: Density-related migration in planthoppers (Homoptera: Delphacidae): the role of habitat persistence. - Am. Nat. 138: 1513-1541.

Denno R.F., Roderick G.K., Peterson M.A., Huberty A.F., Döbel H.G., Eubanks M.D., Losey J.E. \& Langellotto G.A. 1996: Habitat persistence underlies the intraspecific dispersal strategies of planthoppers. - Ecol. Monogr. 66: 389-408.

Denno R.F., Gratton C. \&. Langellotto G.A. 2001: Significance of habitat persistence and dimensionality in the evolution of insect dispersal strategies. In Woiwod I.P., Reynolds D.R. \& Thomas C.D. (eds): Insect Movement: Mechanisms and Consequences. CAB International, Wallingford, pp. 235-259.

Dingle H. 2014: Migration: The Biology of Life on the Move. 2nd ed. Oxford University Press, Oxford, $\mathrm{x}+326 \mathrm{pp}$.

DraKe V.A. \& ReYNolds D.R. 2012: Radar Entomology: Observing Insect Flight and Migration. CABI, Wallingford, xviii + 489 pp.

Freeman J.A. 1939: Studies in the Distribution of Insects by Aerial Currents. A Contribution to the Study of Windborne Insects with Special Reference to Vertical Distribution and Dispersal. $\mathrm{PhD}$ Thesis, University College, Hull, UK.

FREemAn J.A. 1945: Studies in the distribution of insects by aerial currents. The insect population of the air from ground level to 300 feet. - J. Anim. Ecol. 14: 128-154.

GHAURI M.S.K. 1983: A case of long-distance dispersal of a leafhopper. In Knight W.J., Pant N.C., Robertson T.S. \& Wilson M.R. (eds): 1st International Workshop on Leafhoppers and Planthoppers of Economic Importance. Commonwealth Institute of Entomology, London, pp. 249-255.

Glick P.A. 1939: The Distribution of Insects, Spiders and Mites in the Air. Technical Bulletin No. 673, United States Department of Agriculture, Washington, D.C., $151 \mathrm{pp}$.

GLICK P.A. 1960: Collecting Insects by Airplane, with Special Reference to Dispersal of the Potato Leafhopper. Technical Bulletin No. 1222, United States Department of Agriculture, Washington D.C., 28 pp.
GÜNTHART H. 1988: Comparison of the vertical distribution of leafhoppers - trapped between 5 and $155 \mathrm{~m}$ above the ground with the ground population. In Vidano C. \& Arzone A. (eds): $6^{\text {th }}$ Auchenorrhyncha Meeting, Turin, Italy, September 7-11, 1987. Consiglio Nazionale delle Ricerche, Spezial Project IPRA, Italy, pp. 379-386.

HARDY A.C. \& Cheng L. 1986: Studies in the distribution of insects by aerial currents. III. Insect drift over the sea. - Ecol. Entomol. 11: 283-290.

HaRdy A.C. \& Milne P.S. 1938: Studies in the distribution of insects by aerial currents. Experiments in aerial tow-netting from kites. - J. Anim. Ecol. 7: 199-229.

Heong K.L. \& Hardy B. 2009: Planthoppers: New Threats to the Sustainability of Intensive Rice Production Systems in Asia. International Rice Research Institute, Los Baños, Philippines, $460 \mathrm{pp}$.

Hothorn T., Bretz F. \& Westfall P. 2008: Simultaneous inference in general parametric models. - Biometrical J. 50: $346-$ 363.

Hu G., Lim K.S., Horvitz N., Clark S.J., Reynolds D.R., SAPIR N. \& CHAPMAN J.W. 2016: Mass seasonal bioflows of high-flying insect migrants. - Science 354: 1584-1587.

JoHNSON C.G. 1954: Aphid migration in relation to weather. Biol. Rev. 29: 87-118.

JoHnson C.G. 1969: Migration and Dispersal of Insects by Flight. Methuen, London, xxii +763 pp.

Kisimoto R. \& Rosenberg L.J. 1994: Long-distance migration in delphacid planthoppers. In Denno R.F. \& Perfect T.J. (eds): Planthoppers: Their Ecology and Management. Chapman and Hall, New York, pp. 302-322.

Le Quesne W.J. 1960: Hemiptera: Fulgoromorpha. Handbooks for the Identification of British Insects. Vol II, Part 3. Royal Entomological Society, London, $68 \mathrm{pp}$.

Le Quesne W.J. 1965: Hemiptera Cicadomorpha (excluding Deltocephalinae and Typhlocybinae). Handbooks for the Identification of British Insects. Vol II, Part 2(a). Royal Entomological Society, London, $64 \mathrm{pp}$.

Le Quesne W.J. 1969: Hemiptera Cicadomorpha Deltocephalinae. Handbooks for the Identification of British Insects. Vol II, Part 2(b). Royal Entomological Society, London, 84 pp.

Le Quesne W.J. \& Payne K.R. 1981: Cicadellidae (Typhlocybinae) with a Checklist of the British Auchenorrhyncha (Hemiptera, Homoptera). Handbooks for the Identification of British Insects. Vol II, Part 2(c). Royal Entomological Society, London, $95 \mathrm{pp}$.

LEWIS T. \& TAYLOR L.R. 1964: Diurnal periodicity of flight by insects. - Trans. R. Entomol. Soc. Lond. 116: 393-479.

LINDSTEN K. 1979: Planthopper vectors and plant disease agents in Fennoscandia. In Maramorosch K. \& Harris K.F. (eds): Leafhoppers Vectors and Plant Disease Agents. Academic Press, New York, pp. 155-178.

Macaulay E.D.M., Tatchell G.M. \& Taylor L.R. 1988: The Rothamsted Insect Survey '12-metre' suction trap. - Bull. Entomol. Res. 78: 121-129.

MagurRan A.E. 2003: Measuring Biological Diversity. WileyBlackwell, Oxford, 264 pp.

Manurang B., Witsack W., Mehner S., Gruntzig M. \& Fuchs E. 2005: Studies on biology and population dynamics of the leafhopper Psammotettix alienus Dahlb. (Homoptera: Auchenorrhyncha) as vector of Wheat dwarf virus (WDV) in SaxonyAnhalt, Germany. - Z. Pflanzenkr. Pflanzensch. 112: 497-507.

Morris M.G. 1990a: The Hemiptera of two sown calcareous grasslands. I. Colonization and early succession. - J. Appl. Ecol. 27: 367-378. 
Morris M.G. 1990b: The Hemiptera of two sown calcareous grasslands. II. Differences between treatments. - J. Appl. Ecol. 27: 379-393.

Muller H.J. 1981: Die Bedeutung der Dormanzformen fur die Populationsdynamik der Zwergzikade Euscelis incisus (Kbm.) (Homopt., Cicadellidae). - Zool. Jb. Syst. 106: 314-334.

Nickel H. 2003: The Leafhoppers and Planthoppers of Germany (Hemiptera, Auchenorrhyncha): Patterns and Strategies in a Highly Diverse Group of Phytophagous Insects. Pensoft, Sofia \& Moscow and Goecke \& Evers, Keltern, 460 pp.

Nickel H. \& AchtZiger R. 2005: Do they ever come back? Responses of leafhopper communities to extensification of land use. - J. Insect Conserv. 9: 319-333.

Nickel H. \& Hildebrandt J. 2003: Auchenorrhyncha communities as indicators of disturbance (Insecta, Hemiptera) - a case study from the Elbe flood plains (northern Germany). - Agric. Ecosyst. Environ. 98: 183-199.

Nickel H. \& Remane R. 2002: Artenliste der Zikaden Deutschlands, mit Angabe von Nährpflanzen, Nahrungsbreite, Lebenszyklus, Areal und Gefährdung (Hemiptera, Fulgoromorpha et Cicadomorpha). - Beitr. Zikadenk. 5: 27-64.

NovotnÝ V. 1994a: Association of polyphagy in leafhoppers (Auchenorrhyncha, Hemiptera) with unpredictable environments. - Oikos 70: 223-232.

NovotnÝ V. 1994b: Relation between temporal persistence of host plants and wing length in leafhoppers (Auchenorrhyncha, Hemiptera). - Ecol. Entomol. 19: 168-176.

NovotNÝ V. 1995: Relationships between life histories of leafhoppers (Auchenorrhyncha - Hemiptera: and their host plants (Juncaceae, Cyperaceae, Poaceae). - Oikos 73: 33-42.

Отика A. 2013: Migration of rice planthoppers and their vectored re-emerging and novel rice viruses in East Asia. - Front. Microbiol. 4: 309, $11 \mathrm{pp}$.

Otuka A., Matsumura M., Sanada-Morimura S., Takeuchi H., Watanabe T., Ohtsu R. \& Inoue H. 2010: The 2008 overseas mass migration of the small brown planthopper, Laodelphax striatellus, and subsequent outbreak of rice stripe disease in western Japan. - Appl. Entomol. Zool. 45: 259-266.

R Core Team 2016: R: A Language and Environment for Statistical Computing. R Foundation for Statistical Computing, Vienna, URL: https://www.R-project.org/.

RaAtiKAINEN M. 1967: Bionomics, enemies and population dynamics of Javesella pellucida (F.) (Hom., Delphacidae). Ann. Agric. Fenn. (Suppl. 2) 6: 1-149.

RAATIKAINEN M. \& VASARAINEN A. 1973: Early- and high-summer flight periods of leafhoppers. - Ann. Agric. Fenn. 12: 77-94.

Reynolds D.R., Mukhopadhyay S., Riley J.R., Das B.K., Nath P.S. \& MANDAL S.K. 1999: Seasonal variation in the windborne movement of insect pests over northeast India. - Int. J. Pest Manag. 45: 195-205.

Reynolds D.R., Nau B.S. \& Chapman J.W. 2013: High-altitude migration of Heteroptera in Britain. - Eur. J. Entomol. 110: 483-492.

Reynolds D.R., Reynolds A.M. \& Chapman J.W. 2014: Nonvolant modes of migration in terrestrial arthropods. - Anim. Migrat. 2: 8-28.

Riley J.R., Cheng X.-N., Zhang X.-X., Reynolds D.R., Xu G.M., Smith A.D., Cheng J.-Y., Bao A.-D. \& Zhai B.-P. 1991: The long-distance migration of Nilaparvata lugens (Stal) (Delphacidae) in China: Radar observations of mass return flight in the autumn. - Ecol. Entomol. 16: 471-489.

Rose D.J.W. 1978: Epidemiology of maize streak disease. Annu. Rev. Entomol. 23: 259-282.
SALmon M.A. \& Chapman J.W. 2000: On the history and distribution of Athysanus argentarius Metcalf (Hem.: Cicadellidae) in Britain. - Br. J. Entomol. Nat. Hist. 13: 91-93.

Shields E.J. \& Testa A.M. 1999: Fall migratory flight initiation of the potato leafhopper, Empoasca fabae (Homoptera: Cicadellidae): observations in the lower atmosphere using remote piloted vehicles. - Agric. For. Meteorol. 97: 317-330.

Southwood T.R.E. 1960: The flight activity of Heteroptera. Trans. R. Entomol. Soc. Lond. 112: 173-220.

Southwood T.R.E. 1962: Migration of terrestrial arthropods in relation to habitat. - Biol. Rev. 37: 171-214.

Stewart A.J.A. 1988: Patterns of host plant utilisation by leafhoppers in the genus Eupteryx (Hemiptera: Cicadellidae) in Britain. - J. Nat. Hist. 22: 357-379.

STEWART A.J.A. 2002: Techniques for sampling Auchenorrhyncha in grasslands. - Denisia 4: 491-512.

TAYLOR L.R. 1974: Insect migration, flight periodicity and the boundary layer. - J. Anim. Ecol. 43: 225-238.

TAYLOR R.A.J. 1985: Migratory behavior in the Auchenorryncha. In Nault L.R. \& Rodriguez J.G. (eds): The Leafhoppers and Planthoppers. Wiley, New York, pp. 259-287.

TAYLOR R.A.J. 1989: Potato leafhopper migration: the mystery of the return migration. - Misc. Publ. Entomol. Soc. Am. 72: $42-52$.

TAYLOR R.A.J. \& Reling D. 1986: Preferred wind direction of long-distance leafhopper (Empoasca fabae) migrants and its relevance to the return migration of small insects. $-J$. Anim. Ecol. 55: 1103-1114.

TAYLOR L.R., WOIWOD I.P. \& TAYLOR R.A.J. 1979: The migratory ambit of the hop aphid and its significance in aphid population dynamics. - J. Anim. Ecol. 48: 955-972.

Taylor P.S., Shields E.J., Tauber M.J. \& Tauber C.A. 1995: Induction of reproductive diapause in Empoasca fabae (Homoptera, Cicadellidae) and its implications regarding southward migration. - Environ. Entomol. 24: 1086-1095.

TERAGUCHI S.E. 1986: Migration patterns of leafhopper (Homoptera: Cicadellidae) in an Ohio old field. - Environ. Entomol. 15: 1199-1211.

Wainwright C.E., Stepanian P.M., Reynolds D.R. \& Reynolds A.M. 2017: The movement of small insects in the convective boundary layer: linking patterns to processes. - Sci. Rep. 7: 5438,8 pp.

WALOFF N. 1973: Dispersal by flight of leafhoppers (Auchenorrhyncha: Homoptera). - J. Appl. Ecol. 10: 705-730.

WALOFF N. 1983: Absence of wing polymorphism in the arboreal, phytophagous species of some taxa of temperate Hemiptera: an hypothesis. - Ecol. Entomol. 8: 229-232.

WALOFF N. 1994: Observations on Zyginidia scutellaris (HerrichSchaeffer), Auchenorrhyncha: Typhlocybinae, Cicadellidae. The Entomologist 113: 20-27.

Waloff N. \& Solomon M.G. 1973: Leafhoppers (Auchenorrhyncha: Homoptera) of acidic grassland. - J. Appl. Ecol. 10: 189-212.

Waloff N. \& Thompson P. 1980: Census data of populations of some leafhoppers (Auchenorrhyncha, Homoptera) of acid grassland. - J. Anim. Ecol. 49: 395-416.

Walters K.F.A. \& Dixon A.F.G. 1984: The effect of temperature and wind on the flight activity of cereal aphids. - Ann. Appl. Biol. 104: 17-26.

Wilson M., Stewart A., Biedermann R., Nickel H. \& NiedringHaus R. 2015: The Planthoppers and Leafhoppers of Britain and Ireland. Wissenschaftlich Akademischer BuchvertriebFründ, Scheeßel, $138 \mathrm{pp}$.

Received August 3, 2017; revised and accepted November 28, 2017 Published online December 15, 2017 